\title{
Effects of Innovation Education and Corporate Needs -Analysis Using Bayesian Network
}

\author{
Tsuyoshi Aburai ${ }^{1}$, Kazuhiro Takeyasu ${ }^{2}$ \\ ${ }^{1}$ Tokushima University Research Center for Higher Education Division of Academic Learning Support Section of \\ Innovation Education, Japan \\ ${ }^{2}$ Research Institute for Management Information System, Japan \\ Correspondence: Tokushima University Research Center for Higher Education Division of Academic Learning \\ Support Section of Innovation Education, 2-1 Minamijosanjimacho, Tokushima, Japan.
}

Received: October 16, 2020

Accepted: November 18, 2020

Online Published: November 24, 2020

doi:10.5539/ibr.v13n12p51

URL: https://doi.org/10.5539/ibr.v13n12p51

\begin{abstract}
This paper offers a clarification of the skills required for innovation talent by comparing the effect of innovation in education at Tokushima University and the talent requirement of companies. The researchers performed the questionnaire investigation with the use of the 19 items of The Innovator's DNA Skill Assessment. Both the basic statistical analysis and Bayesian Network analysis were conducted based on the resulting data. The sensitivity analysis was performed after building the Bayesian Network Model. The evidences are set to "skeptical thinking", "taking risks", and "creativity" in the item of mind. The calculation of the odds ratio reveals that enhancing the Observation skill and Skill to Plan and Design is effective in improving skeptical thinking and creativity.
\end{abstract}

Keywords: innovation education, design thinking, academic industrial collaboration, Bayesian network

\section{Introduction}

The ideal business setting is to sell products that are produced based on consumers' needs. However, in many cases, products are produced based on the resources available to companies. Businesses may find this challenging as user's preferences tend to change over time, making it difficult to make a product that fits well in the market. Another reason for this is that market is matured by the mass production and one to one marketing is required to conquer that (Takeyasu, K., et al., 2013). Our university barely presents a systematic instruction to search for users' needs, and this is despite the transition from seeds orientation to needs orientation of most businesses.

The extracurricular activities "Innovation challenge club" under Academic Industrial Collaboration (AIC) for undergraduate has launched since April 2018 in Tokushima University. It aims to solve the job and talent mismatch issues faced by companies located in Tokyo and Osaka. As far as this theme concerned, it is a unique approach made by Tokushima University and cannot be found in other universities. They intended to make final presentation on October 2018. Table 1 shows the themes of the collaborating companies. The companies' participating staffs belong to business departments and research development departments. Further, design thinking was tested on the graduate students of technical management advanced course at university during April to July 2018. Application of this design thinking method to the existing problem under the collaboration with university and companies may be the first one as we cannot find any former researches.

In this paper, the author offers an examination of the skills needed for innovation talent by comparing the innovation education taught at Tokushima University and the skills most companies require. 
Table 1. Themes of the companies

\begin{tabular}{|l|l|}
\hline Company name & Theme \\
\hline JTEKT Corporation & $\begin{array}{l}\text { Commodity for consumers and business model utilizing bearing } \\
\text { (JTEKT Corporation is a big manufacturer which produces bearings.) }\end{array}$ \\
\hline Panasonic Cycle Technology Co., Ltd. & $\begin{array}{l}\text { Electro motion bicycle which changes Tokushima district's traffic } \\
\text { infrastructure }\end{array}$ \\
\hline YANMAR Co., Ltd & $\begin{array}{l}\text { Autonomous robot shade from bird } \\
\text { YANMAR Co. owns three exersize practice fields for football team. Ducks } \\
\text { take rest in winter there and eat the lawn roots and defacate. Therefore robots } \\
\text { which drive off ducks are developed. }\end{array}$ \\
\hline YKK CORPORATION & $\begin{array}{l}\text { Development of application of self-propelling fastener } \\
\text { Fastener with small motor run automatically by the remote control of smart } \\
\text { phone. }\end{array}$ \\
\hline
\end{tabular}

\section{Solve the Companies' Issue by the Design Thinking}

In design thinking, sympathizing with the consumers, such as knowing their inconveniences, is the first step to develop new products or services. The user's feedback on their experience about the prototype of the product is critical during the development stage. A better product is created by repeating the improvement based upon the user's feedback. In this instance, a simple version is presented for the product prototype. This strategy is favorable as it allows for efficient and timely product development according to customer specifications.

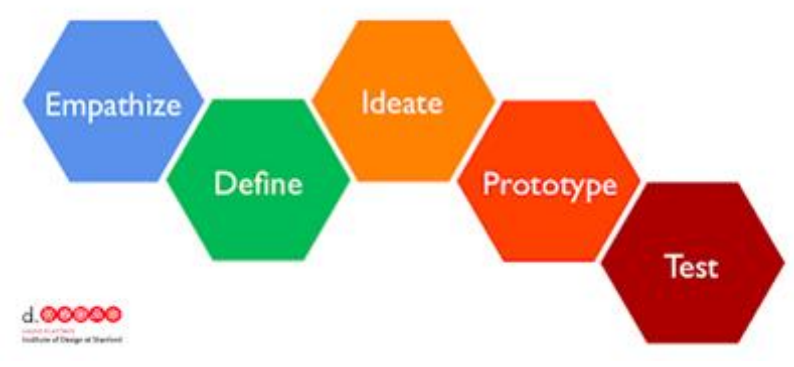

Figure 1. Process of design thinking (http://beyondthenexus.com/designthinking_empathy_innovation/)

\section{Outline of the Questionnaire Investigation}

The researchers performed the questionnaire investigation with the use of the 19 items of The Innovator's DNA Skill Assessment. The resulting data served as a basis in conducting both basic statistical analysis and Bayesian Network analysis.

Innovator's DNA Skill Assessment is a diagnostic tool developed by Clayton Professor of Harvard Business School. It is comprised of 19 items that are classified in 4 divisions, namely Skill, Mind, Skill to execute, Skill of inducing others the innovation as shown in Table 2. 
Table 2. The Innovator's DNA Skill Assessment 19 items (The Innovator's DNA https://innovatorsdna.com/）

\begin{tabular}{|l|l|}
\hline \multirow{5}{*}{ Skill } & Skill to associate \\
\cline { 2 - 2 } & Skill to inquire \\
\cline { 2 - 2 } & Observation skill \\
\cline { 2 - 2 } & Skill to make experiment \\
\cline { 2 - 2 } & Networking skill \\
\hline \multirow{5}{*}{ Skill to execute } & Skeptical thinking \\
\cline { 2 - 2 } & Taking risks \\
\cline { 2 - 2 } & Creativity \\
\hline Skill of inducing others the innovation & Skill to analyze \\
\cline { 2 - 2 } & Skill to plan and design \\
\cline { 2 - 2 } & Introducing skill \\
\cline { 2 - 2 } & Skill to execute \\
\hline \multirow{5}{*}{} & Skill to induce the others to associate \\
\cline { 2 - 2 } & Skill to induce the question of the other members \\
\cline { 2 - 2 } & Skill to induce other members to observe \\
\cline { 2 - 2 } & Skill to induce other members to make experiment \\
\cline { 2 - 2 } & Skill to induce other members to have networking skill \\
\cline { 2 - 2 } & Skill to induce other members to challenge the current status \\
\cline { 2 - 2 } & Skill to induce other members to take risk \\
\hline
\end{tabular}

The outline of the questionnaire investigation is as follows

1) Scope of investigation: Students who took innovation education, Collaborated companies

2) Date: July $17 \sim$ September 192018

3) Method: Self writing to the questionnaire sheet

4) Collection: Number of distribution 50, Number of collection 41 (Collection rate 82\%), Valid answer 41

\section{Basic Statistical Results}

Now, we show the main summary results by single variable.

4.1 Sex

Male 34, Female 4

These are exhibited in Figure 2.

$83 \%$ are the male.

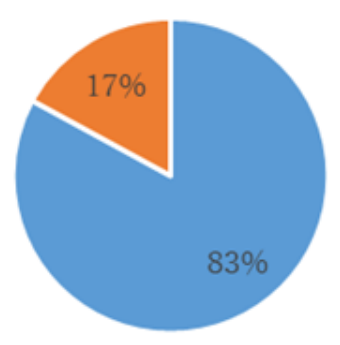

" Male $=$ Female

Figure 2. Sex

\subsection{Affiliation}

Undergraduate 21, Graduated students15

Company members 5 (JTEKT Corporation 1, Panasonic Cycle Technology Co., Ltd. 1, YANMAR Co., Ltd 2, YKK CORPORATION 1) (Figure 3). 


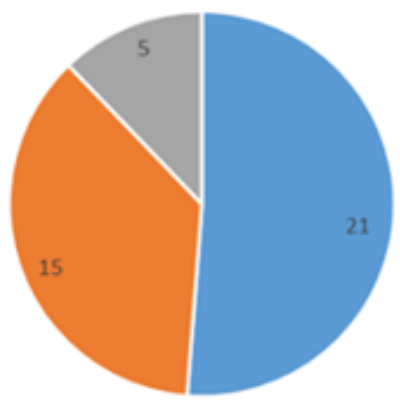

- Undergraduate - Graduated student = Companymembers

Figure 3. Affiliation

\subsection{Innovation Index}

Students have selected the rank of item which is classified into 5 (stage $1 \sim$ stage 5 ) where their skill have advanced. As for the company employee, they have selected the rank of item which is classified into 5 (stage $1 \sim$ stage 5) which is required as the innovation talent.

\subsubsection{Undergraduate}

From Figure 4, we observe that most of the item in the most advanced skill is Net-working skill (Skill) and then Skill to associate (Skill), Skeptical thinking (Mind) and Skill to inquire (Skill) follow.

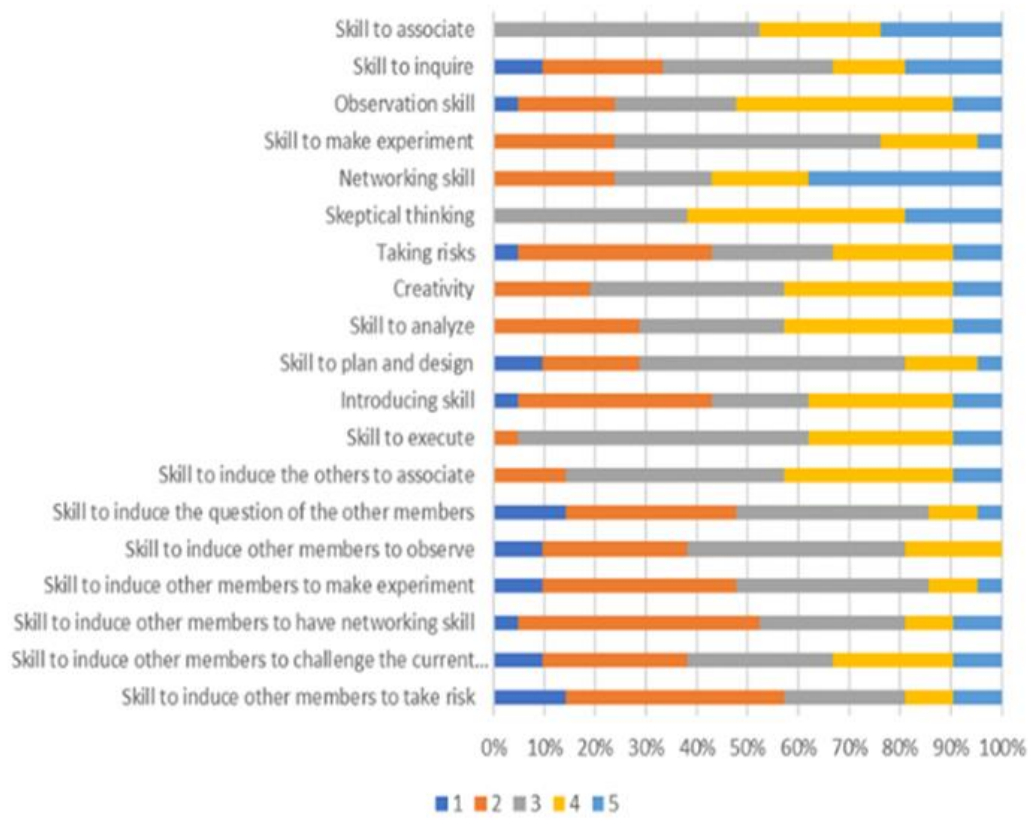

Figure 4. Undergraduate

\subsubsection{Graduated Students}

From Figure 5, we observe that most of the item in the most advanced skill is Networking skill (Skill) and then Creativity (Mind), Skill to plan and design (Skill to execute), Observation skill (Skill) follow. 


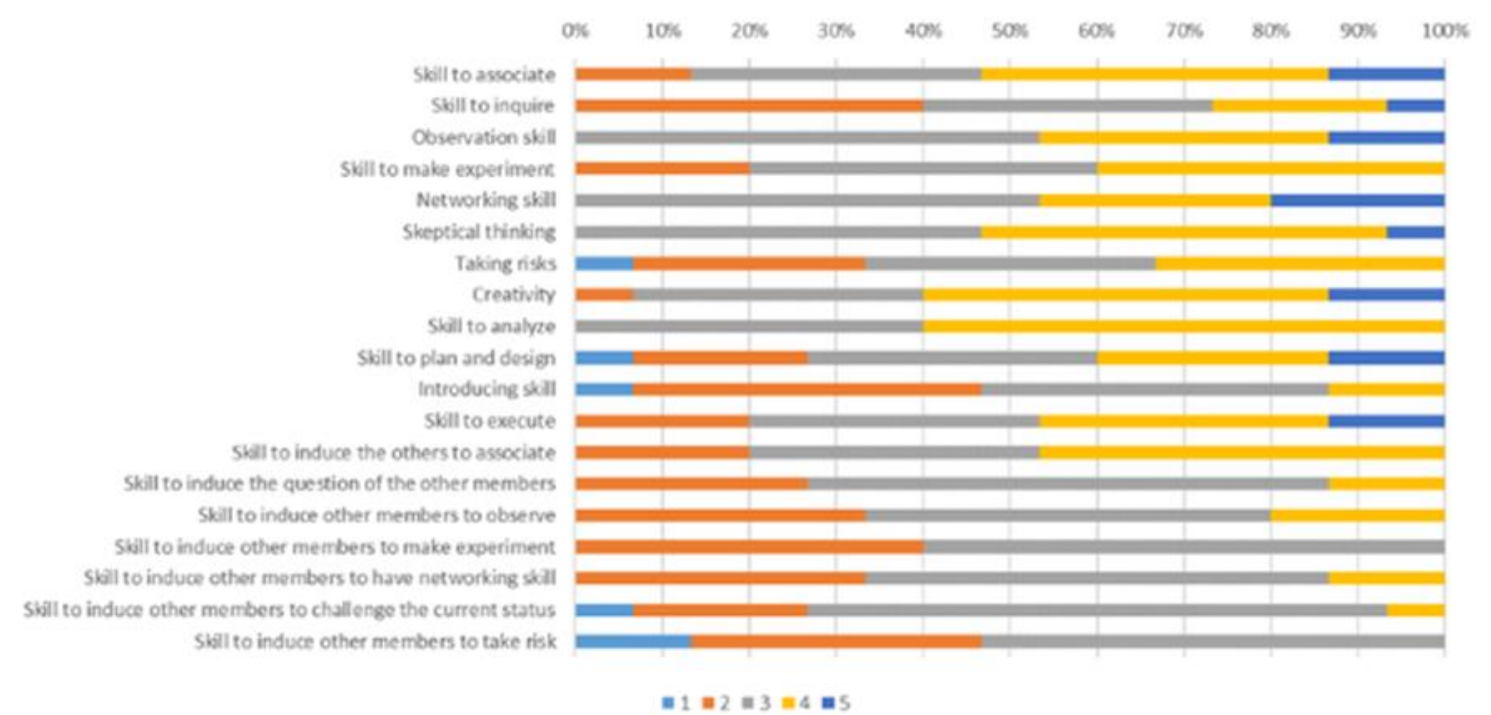

Figure 5. Graduated students

\subsubsection{Company Employee}

From Figure 6, we observe that most of the three items in the most advanced skill is Skeptical thinking (Mind), Skill to inquire (Skill) and Skill to plan and design (Skill to execute).

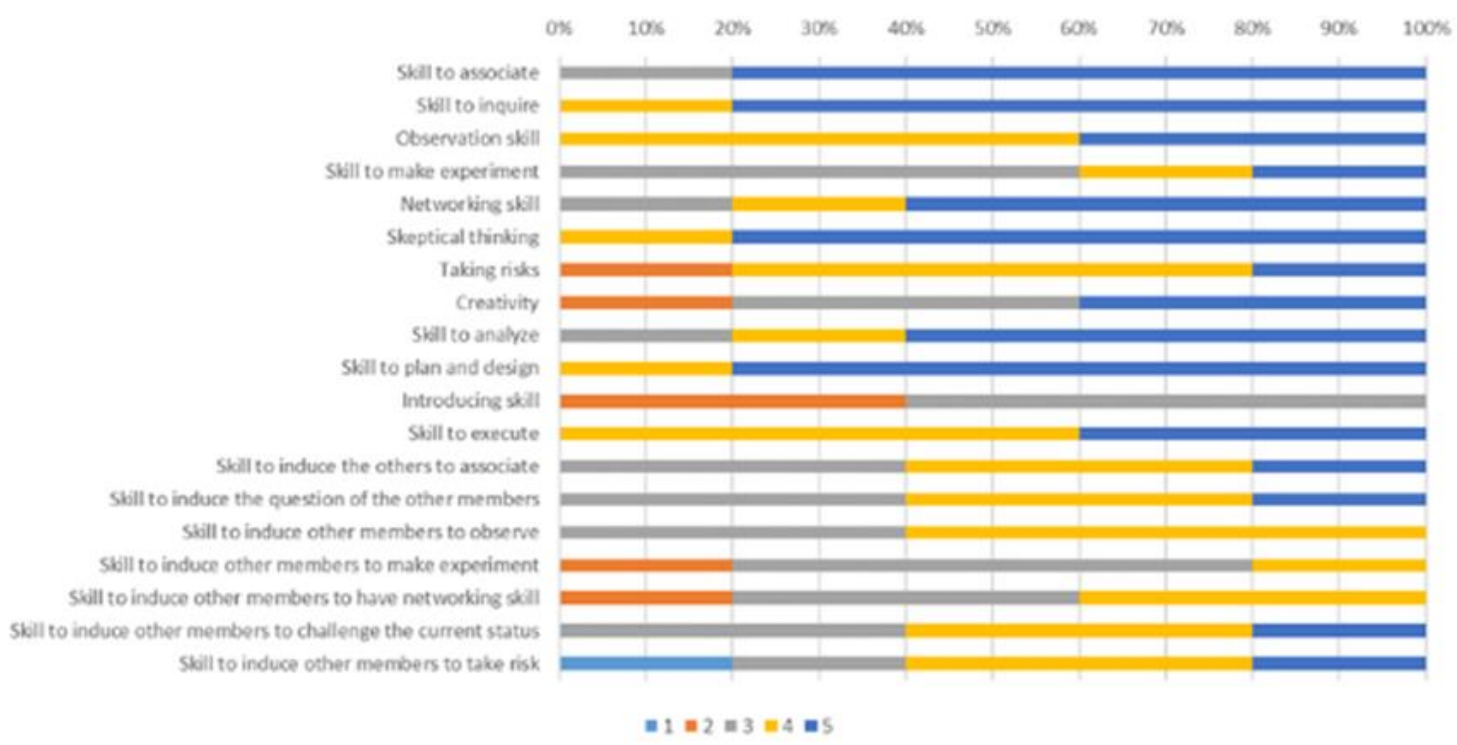

\section{Bayesian Network Analysis}

Figure 6. Company employee

In recent years, Bayesian Network is highlighted because it has the following good characteristics (Neapolitan, R.E., 2004).

-Structural Equation Modeling requires normal distribution to the data in the analysis. Therefore it has a limitation in making analysis. But Bayesian Network does not require specific distribution type to the data. It can handle any distribution type.

-It can handle the data which include partial data.

-Expert's know-how can be reflected in building Bayesian Network model.

- Sensitivity analysis can be easily executed by settling evidence. We can estimate and predict the prospective purchaser by that analysis. 
-It is a probability model having network structure. Related items are connected with directional link. Therefore understanding becomes easy by its visual chart.

In this research, it is suitable to utilize Bayesian Network to analyze this questionnaire investigation.

The construction of the Bayesian Network model requires checking the causal relationship among groups of items. It is because the Bayesian Network is constructed by the link of items and there should be causal relationship when making links. We used BAYONET software found at http://www.msi.co.jp/BAYONET/ for this purpose. The existence of plural nodes in the same group results in the difficult of determining a causal relationship. The BAYONET system is useful in this case as it utilizes the AIC standard to set the sequence automatically.

The implication of the research outcome in relation to innovation education relates with the importance of building the model and utilizing the AIC standard.

Based on this, a model is built as is shown in Figure 7.

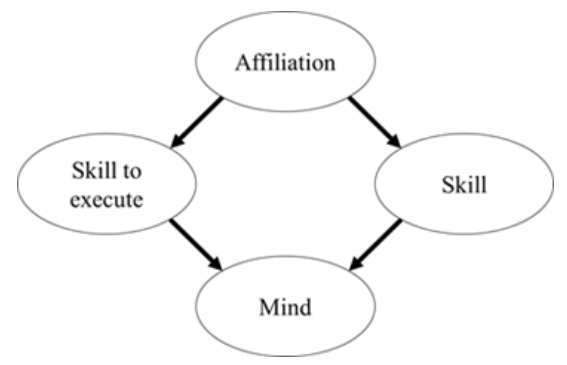

Figure 7. Built model

\section{Sensitivity Analysis}

Sensitivity analysis is executed based on the evidence gathered for each item. We select the "Mind" where the companies require. This resonates with the requirements of most companies, wherein the mind category comprised of "Skeptical thinking", "Taking risks" and "Creativity". The change of innovation index is captured by comparing the Prior probability and Posterior probability. Appendix 3 shows the calculation results of Posterior probability after setting evidence to each item. Odds ratio is calculated in order to make change rate clear (Table 3).

Table 3. Prior probability, Posterior probability and odds ratio

\begin{tabular}{|c|c|c|c|c|c|}
\hline & \multirow{2}{*}{$\begin{array}{c}\text { Prior } \\
\text { probability }\end{array}$} & \multicolumn{3}{|c|}{ Mind } \\
\hline & & & $\begin{array}{l}\text { Skeptical thinking } \\
\text { Odds ratio }\end{array}$ & $\begin{array}{c}\text { Taking risks Odds } \\
\text { ratio }\end{array}$ & $\begin{array}{l}\text { Creativity Odds } \\
\text { ratio }\end{array}$ \\
\hline \multirow{5}{*}{ Skill } & Skill to associate & 0.496 & 1.002 & 1.001 & 1.002 \\
\hline & Skill to inquire & 0.370 & 1.002 & 1.002 & 1.002 \\
\hline & Observation skill & 0.514 & 1.002 & 1.002 & 1.003 \\
\hline & $\begin{array}{l}\text { Skill to make } \\
\text { experiment }\end{array}$ & 0.318 & 1.000 & 1.002 & 1.002 \\
\hline & Networking skill & 0.518 & 1.002 & 1.000 & 1.002 \\
\hline \multirow{4}{*}{$\begin{array}{l}\text { Skill to } \\
\text { execute } \\
\text { and } \\
\text { promote }\end{array}$} & Skill to analyze & 0.496 & 1.001 & 1.002 & 1.002 \\
\hline & $\begin{array}{l}\text { Skill to plan and } \\
\text { design }\end{array}$ & 0.348 & 1.003 & 1.002 & 1.003 \\
\hline & Introducing skill & 0.265 & 0.999 & 0.999 & 1.000 \\
\hline & Skill to execute & 0.451 & 1.002 & 1.002 & 1.002 \\
\hline
\end{tabular}

The result of this analysis reveals that enhancing the [Skill to plan and design] (Skill to execute) is effective for improving Skeptical thinking ability with respect to odds ratio equal to 1.003 in Table 3. Furthermore, it also shows that enhancing the Observation skill (Skill) and Skill to plan and design (Skill to execute) is effective for improving creativity. 


\section{Conclusion}

Tokushima University has since integrated innovation education in its system. A questionnaire investigation is executed to examine the skills required for the innovation talent by comparing the effect of innovation education at Tokushima University with the company requirements.

Based upon these data, basic statistical analysis and Bayesian Network analysis are conducted. Bayesian Network model is built and the sensitivity analysis is performed.

The result of this study reveals that enhancing the Observation skill and Skill to plan and design is effective for strengthening Skeptical thinking and Creativity.

These results would properly be implicated in the companies' business administration.

Based upon these analyses, innovation education in our university should be revised so as to meet the companies' requirement of talent as was made clear.

Although it has a limitation that it is restricted in the number of questionnaire investigation, further consecutive research will make it more adequate and bear better results.

\section{References}

BAYONET Users' Case, (In Japanese), NTT DATA Mathematical Systems Inc.

Human Resource Image and Organization Image which create innovation (In Japanese) (2013). Nomura Research Insti-tute.

Kurokawa, T. (2012). Design Thinking Education in University and Over Graduated Course (In Japanese) (pp. 10-23). Science \& Technology Trends.

Questionnaire Investigation for the creation of new business and the development and utilization of human resources (In Japanese) (2011). Ministry of Economy, Trade and Industry.

Saito, S., Sakamoto, H., Takeda, Y., Sumi, M., \& Ouchi, T. (2017). A Guide to Design Thinking for Engineers (In Japanese). Shoueisha Publishing.

Takeyasu, K., Ishii, Y., \& Higuchi, Y. (2013). Modern Management Information System (In Japanese). Chuoukeizaisha Publisihing.

http://www.msi.co.jp/bayonet/cases.html

https://innovatorsdna.com/ 


\section{Appendix A}

\section{Questionnaire Investigation}

Self-Evaluation Check Sheet (Undergraduate, Graduated students) 2018

Facult ( ) Department ( Grade ( )

Name (

\section{) Department (}

) Grade ( )

Select rank of item which fit most to you and set five $\odot$ at which your skill has advanced.

\begin{tabular}{|c|c|c|c|c|c|c|}
\hline \multicolumn{7}{|c|}{\begin{tabular}{l|l}
$\begin{array}{l}\text { Your skill } \\
\text { has } \\
\text { advanced } \\
\text { (Set 5 } 5 \text { ) }\end{array}$ & Items \\
\end{tabular}} \\
\hline & Skill to associate & 1 & 2 & 3 & 4 & 5 \\
\hline & \multicolumn{6}{|l|}{ Skill to combine plural elements or ideas } \\
\hline & Skill to inquire & 1 & 2 & 3 & 4 & 5 \\
\hline & \multicolumn{6}{|l|}{ Skill to grasp users' insight and/or essence not to do it by the hypothesis verification } \\
\hline & Observation skill & 1 & 2 & 3 & 4 & 5 \\
\hline & \multicolumn{6}{|l|}{ Skill to observe the fact thoroughly } \\
\hline & Skill to make experiment & 1 & 2 & 3 & 4 & 5 \\
\hline & \multicolumn{6}{|l|}{ Experiment skill to evaluate users as well as thinking } \\
\hline & Networking skill & 1 & 2 & 3 & 4 & 5 \\
\hline & \multicolumn{6}{|l|}{ Skill to utilize the others wisdom } \\
\hline & Skeptical thinking & 1 & 2 & 3 & 4 & 5 \\
\hline & \multicolumn{6}{|l|}{ Skill to demonstrate about current condition } \\
\hline & Taking risks & 1 & 2 & 3 & 4 & 5 \\
\hline & \multicolumn{6}{|l|}{ Skill to take risk resolutely } \\
\hline & Creativity & 1 & 2 & 3 & 4 & 5 \\
\hline & \multicolumn{6}{|l|}{ Confidence to bear creative idea } \\
\hline & Skill to analyze & 1 & 2 & 3 & 4 & 5 \\
\hline & \multicolumn{6}{|l|}{ Skill to analyze, combine, and check from other points } \\
\hline & Skill to plan and design & 1 & 2 & 3 & 4 & 5 \\
\hline & \multicolumn{6}{|l|}{ Skill to plan, design and promote for the further step } \\
\hline & Introducing skill & 1 & 2 & 3 & 4 & 5 \\
\hline & \multicolumn{6}{|l|}{ Skill to introduce innovation tool to the team member } \\
\hline & Skill to execute & 1 & 2 & 3 & 4 & 5 \\
\hline & \multicolumn{6}{|l|}{ Skill to execute with discipline in order to perform systematically } \\
\hline & Skill to induce the others to associate & 1 & 2 & 3 & 4 & 5 \\
\hline & \multicolumn{6}{|l|}{ Skill to induce the other members to have the power of combining the plural elements and ideas } \\
\hline & Skill to induce the question of the other members & 1 & 2 & 3 & 4 & 5 \\
\hline & \multicolumn{6}{|c|}{ Skill to induce other members to grasp users' insight and/or essence not to do it by the hypothesis verification } \\
\hline & Skill to induce other members to observe & 1 & 2 & 3 & 4 & 5 \\
\hline & \multicolumn{6}{|l|}{ Skill to induce other members to observe the fact thoroughly } \\
\hline & Skill to induce other members to make experiment & 1 & 2 & 3 & 4 & 5 \\
\hline & \multicolumn{6}{|l|}{ Skill to induce other members to have experiment skill to evaluate users as well as thinking } \\
\hline & Skill to induce other members to have networking skill & 1 & 2 & 3 & 4 & 5 \\
\hline & \multicolumn{6}{|l|}{ Skill to induce other members to utilize the others wisdom } \\
\hline & Skill to induce other members to challenge the current status & 1 & 2 & 3 & 4 & 5 \\
\hline & \multicolumn{6}{|l|}{ Skill to induce other members to remonstrate about current condition } \\
\hline & Skill to induce other members to take risk & 1 & 2 & 3 & 4 & 5 \\
\hline & Skill to induce other members to take risk resolutely & & & & & \\
\hline
\end{tabular}


Guideline for the evaluation of $1 \sim 5$

1. There is no experience

2. Have little bit experience but cannot have confidence

3. Have confidence to some extent

4. Maybe superior compared with others

5. Have enough experience

\section{Appendix B}

Questionnaire Investigation

Innovation talent (Company employee) 2018

\section{Company name ( ) Name (}

Select rank of item which is required as the innovation talent and set five $\bigcirc$ in which innovation talent is re-quired.

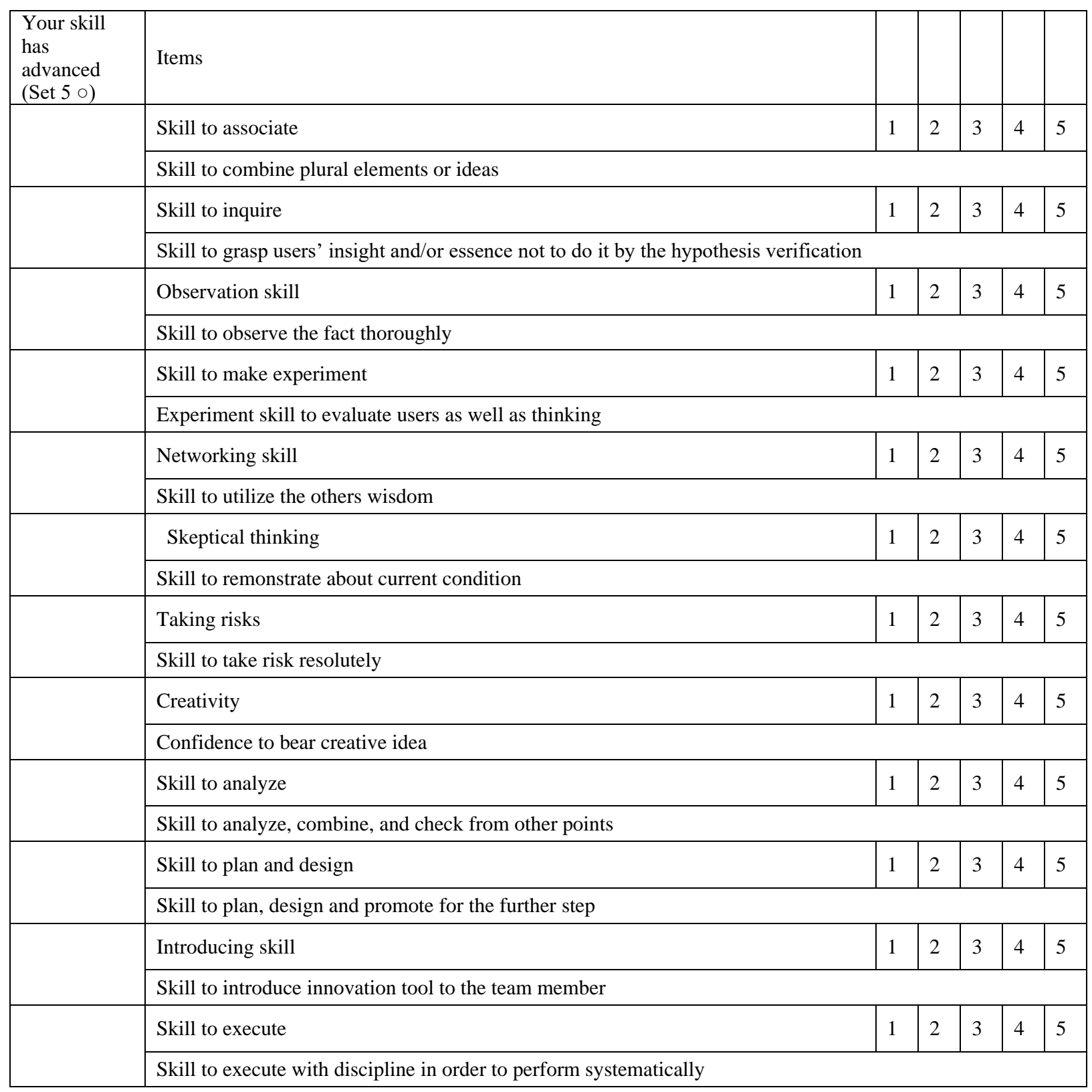




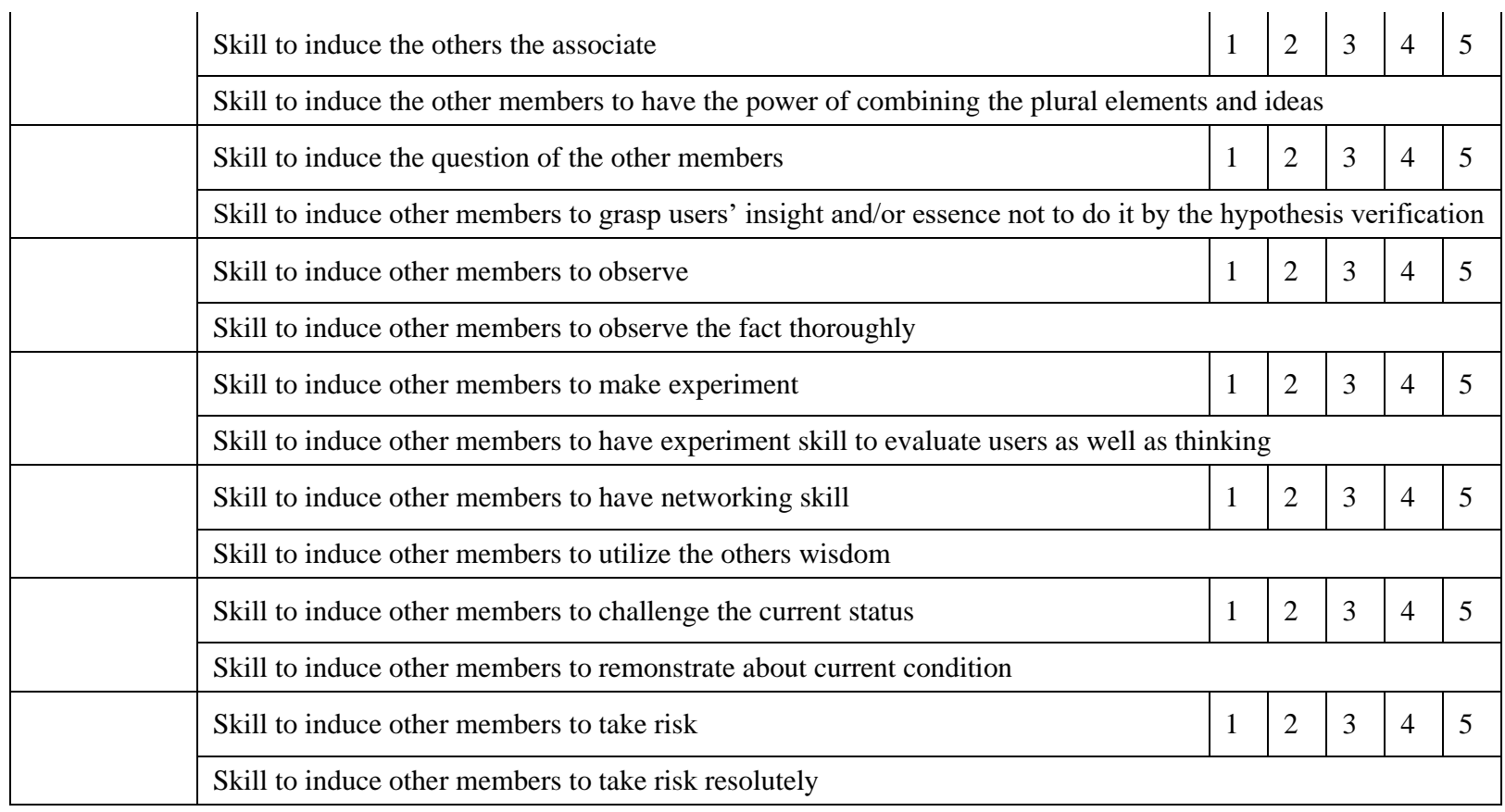

Guideline for the evaluation of $1 \sim 5$

1. There is no need

2. Have little bit need

3. Better to have it

4. Required to some extent

5. Essential

\section{Appendix C}

Prior probability, Posterior probability and odds ratio

\begin{tabular}{|c|c|c|c|c|c|c|}
\hline & \multirow[b]{2}{*}{$\begin{array}{c}\text { Prior } \\
\text { probability }\end{array}$} & \multicolumn{4}{|c|}{ Affiliation } \\
\hline & & & $\begin{array}{c}\text { Company } \\
\text { Posterior probability }\end{array}$ & Company Odds ratio & $\begin{array}{c}\text { Undergraduate } \\
\text { Posterior } \\
\text { probability }\end{array}$ & $\begin{array}{l}\text { Undergraduate } \\
\text { Odds ratio }\end{array}$ \\
\hline \multirow{3}{*}{ Affiliation } & Company & 0.136 & 1 & - & 0 & 0.000 \\
\hline & Undergraduate & 0.500 & 0 & 0 & 1 & - \\
\hline & \begin{tabular}{|l|}
$\begin{array}{l}\text { Graduated } \\
\text { students }\end{array}$ \\
\end{tabular} & 0.364 & 0 & 0 & 0 & 0.000 \\
\hline \multirow{5}{*}{ Skill } & Skill to associate & 0.496 & 0.625 & 1.692 & 0.458 & 0.859 \\
\hline & Skill to in quire & 0.370 & 0.750 & 5.109 & 0.333 & 0.852 \\
\hline & Observation skill & 0.514 & 0.750 & 2.838 & 0.500 & 0.946 \\
\hline & \begin{tabular}{|l|} 
Skill to make \\
experiment
\end{tabular} & 0.318 & 0.375 & 1.289 & 0.250 & 0.716 \\
\hline & Networking skill & 0.518 & 0.625 & 1.553 & 0.542 & 1.101 \\
\hline \multirow{3}{*}{ Mind } & Skeptical thinking & 0.501 & 0.506 & 1.021 & 0.501 & 0.999 \\
\hline & Taking risks & 0.334 & 0.338 & 1.021 & 0.333 & 0.999 \\
\hline & Creativity & 0.334 & 0.338 & 1.018 & 0.334 & 0.999 \\
\hline \multirow{4}{*}{$\begin{array}{l}\text { Skill to } \\
\text { execute } \\
\text { and } \\
\text { promote }\end{array}$} & Skill to analyze & 0.496 & 0.625 & 1.696 & 0.417 & 0.727 \\
\hline & $\begin{array}{l}\text { Skill to plan and } \\
\text { design }\end{array}$ & 0.348 & 0.750 & 5.624 & 0.208 & 0.493 \\
\hline & Introducing skill & 0.265 & 0.125 & 0.396 & 0.375 & 1.663 \\
\hline & Skill to execute & 0.451 & 0.750 & 3.646 & 0.375 & 0.729 \\
\hline
\end{tabular}




\begin{tabular}{|r|r|r|r|r|r|}
\hline \multicolumn{2}{|c|}{ Affiliation } & \multicolumn{4}{|c|}{ Skill } \\
\hline $\begin{array}{c}\text { Graduated } \\
\text { students } \\
\text { Posterior } \\
\text { probability }\end{array}$ & $\begin{array}{c}\text { Graduated } \\
\text { students Odds } \\
\text { ratio }\end{array}$ & $\begin{array}{c}\text { Skill to associate } \\
\text { Posterior } \\
\text { probability }\end{array}$ & $\begin{array}{c}\text { Skill to associate Odds } \\
\text { ratio }\end{array}$ & $\begin{array}{c}\text { Skill to inquire } \\
\text { Posterior } \\
\text { probability }\end{array}$ & $\begin{array}{c}\text { Skill to inquire } \\
\text { Odds ratio }\end{array}$ \\
\hline 0 & 0.000 & 0.172 & 1.313 & 0.276 & 2.420 \\
\hline 0 & 0.000 & 0.462 & 0.858 & 0.451 & 0.820 \\
\hline 1 & - & 0.366 & 1.012 & 0.273 & 0.657 \\
\hline 0.500 & 1.015 & 1 & - & 0.516 & 1.081 \\
\hline 0.278 & 0.655 & 0.385 & 1.064 & 1 & - \\
\hline 0.444 & 0.757 & 0.523 & 1.035 & 0.554 & 1.175 \\
\hline 0.389 & 1.368 & 0.322 & 1.022 & 0.322 & 1.023 \\
\hline 0.444 & 0.745 & 0.520 & 1.011 & 0.538 & 1.086 \\
\hline 0.501 & 1.000 & 0.501 & 1.003 & 0.502 & 1.004 \\
\hline 0.334 & 1.000 & 0.334 & 1.001 & 0.334 & 1.003 \\
\hline 0.334 & 1.000 & 0.334 & 1.001 & 0.334 & 1.003 \\
\hline 0.556 & 1.272 & 0.503 & 1.032 & 0.512 & 1.069 \\
\hline 0.389 & 1.193 & 0.368 & 1.089 & 0.407 & 1.289 \\
\hline 0.167 & 0.554 & 0.256 & 0.952 & 0.249 & 0.919 \\
\hline 0.444 & 0.972 & 0.465 & 1.056 & 0.498 & 1.204 \\
\hline
\end{tabular}

\begin{tabular}{|r|r|r|r|r|r|}
\hline \multicolumn{1}{|c|}{$\begin{array}{c}\text { Observation skill } \\
\text { Posterior } \\
\text { probability }\end{array}$} & $\begin{array}{c}\text { Observation skill } \\
\text { Odds ratio }\end{array}$ & $\begin{array}{c}\text { Skill to make } \\
\text { experiment } \\
\text { Posterior } \\
\text { probability }\end{array}$ & $\begin{array}{c}\text { Skill to make } \\
\text { experiment Odds } \\
\text { ratio }\end{array}$ & $\begin{array}{c}\text { Networking skill } \\
\text { Posterior } \\
\text { probability }\end{array}$ & $\begin{array}{c}\text { Networking skill Odds } \\
\text { ratio }\end{array}$ \\
\hline 0.199 & 1.574 & 0.161 & 1.216 & 0.165 & 1.248 \\
\hline 0.486 & 0.947 & 0.394 & 0.649 & 0.523 & 1.097 \\
\hline 0.314 & 0.803 & 0.445 & 1.405 & 0.312 & 0.794 \\
\hline 0.505 & 1.034 & 0.504 & 1.031 & 0.499 & 1.010 \\
\hline 0.399 & 1.130 & 0.376 & 1.025 & 0.385 & 1.064 \\
\hline 1 & - & 0.516 & 1.007 & 0.524 & 1.041 \\
\hline 0.319 & 1.005 & 1 & - & 0.314 & 0.983 \\
\hline 0.528 & 1.041 & 0.512 & 0.977 & 1.002 & 1.002 \\
\hline 0.501 & 1.003 & 0.501 & 1.000 & 0.501 & 1.002 \\
\hline 0.334 & 1.001 & 0.334 & 1.002 & 0.333 & 0.995 \\
\hline 0.334 & 1.003 & 0.334 & 1.002 & 0.334 & 1.027 \\
\hline 0.502 & 1.025 & 0.512 & 1.068 & 0.494 & 1.019 \\
\hline 0.373 & 1.115 & 0.376 & 1.130 & 0.354 & 1.029 \\
\hline 0.260 & 0.972 & 0.242 & 0.885 & 0.269 & \\
\hline 0.471 & 1.084 & 0.466 & 1.062 & 0.458 & \\
\hline
\end{tabular}




\begin{tabular}{|r|r|r|r|r|r|}
\hline \multicolumn{7}{|c|}{ Mind } \\
\hline $\begin{array}{c}\text { Skeptical thinking } \\
\text { Posterior } \\
\text { probability }\end{array}$ & $\begin{array}{c}\text { Skeptical thinking } \\
\text { Odds ratio }\end{array}$ & $\begin{array}{c}\text { Taking risks } \\
\text { Posterior } \\
\text { probability }\end{array}$ & $\begin{array}{c}\text { Taking risks Odds } \\
\text { ratio }\end{array}$ & $\begin{array}{c}\text { Creativity } \\
\text { Posterior } \\
\text { probability }\end{array}$ & $\begin{array}{c}\text { Creativity Odds } \\
\text { ratio }\end{array}$ \\
\hline 0.137 & 1.003 & 0.137 & 1.003 & 0.137 & 1.004 \\
\hline 0.500 & 0.999 & 0.500 & 0.998 & 0.500 & 0.998 \\
\hline 0.364 & 1.000 & 0.364 & 1.000 & 0.364 & 1.000 \\
\hline 0.497 & 1.002 & 0.497 & 1.001 & 0.497 & 1.002 \\
\hline 0.370 & 1.002 & 0.370 & 1.002 & 0.370 & 1.002 \\
\hline 0.514 & 1.002 & 0.514 & 1.002 & 0.515 & 1.003 \\
\hline 0.318 & 1.000 & 0.318 & 1.002 & 0.318 & 1.002 \\
\hline 0.518 & 1.002 & 0.518 & 1.000 & 0.518 & 1.002 \\
\hline 1 & - & 0.501 & 1.000 & 0.501 & 1.000 \\
\hline 0.334 & 1.000 & 1 & - & 0.334 & 1.000 \\
\hline 0.334 & 1.000 & 0.334 & 1.000 & 1 & - \\
\hline 0.496 & 1.001 & 0.496 & 1.002 & 0.496 & 1.002 \\
\hline 0.348 & 1.003 & 0.348 & 1.002 & 0.348 & 1.003 \\
\hline 0.265 & 0.999 & 0.265 & 0.999 & 0.265 & 1.000 \\
\hline 0.452 & 1.002 & 0.452 & 1.002 & 0.452 & 1.002 \\
\hline
\end{tabular}

\begin{tabular}{|c|c|c|c|c|c|c|c|}
\hline \multicolumn{8}{|c|}{ Skill to execute and promote } \\
\hline $\begin{array}{c}\text { Skill to analyze } \\
\text { Posterior } \\
\text { probability } \\
\end{array}$ & $\begin{array}{l}\text { Skill to analyze } \\
\text { Odds ratio }\end{array}$ & $\begin{array}{l}\text { Skill to plan } \\
\text { and design } \\
\text { Posterior } \\
\text { probability }\end{array}$ & $\begin{array}{c}\text { Skill to plan and } \\
\text { design } \\
\text { Odds ratio } \\
\end{array}$ & $\begin{array}{c}\text { Introducing } \\
\text { skill } \\
\text { Posterior } \\
\text { probability }\end{array}$ & $\begin{array}{l}\text { Introducing skill } \\
\text { Odds ratio }\end{array}$ & $\begin{array}{c}\text { Skill to } \\
\text { execute } \\
\text { Posterior } \\
\text { probability }\end{array}$ & $\begin{array}{l}\text { Skill to execute } \\
\text { Odds ratio }\end{array}$ \\
\hline 0.172 & 1.315 & 0.294 & 2.638 & 0.064 & 0.435 & 0.227 & 1.855 \\
\hline 0.420 & 0.725 & 0.299 & 0.427 & 0.707 & 2.415 & 0.415 & 0.711 \\
\hline 0.408 & 1.204 & 0.407 & 1.199 & 0.229 & 0.519 & 0.358 & 0.976 \\
\hline 0.504 & 1.032 & 0.524 & 1.119 & 0.479 & 0.932 & 0.511 & 1.061 \\
\hline 0.382 & 1.054 & 0.433 & 1.302 & 0.347 & 0.907 & 0.408 & 1.173 \\
\hline 0.520 & 1.026 & 0.551 & 1.160 & 0.503 & 0.959 & 0.537 & 1.096 \\
\hline 0.328 & 1.050 & 0.343 & 1.123 & 0.290 & 0.877 & 0.328 & 1.049 \\
\hline 0.516 & 0.995 & 0.527 & 1.037 & 0.525 & 1.029 & 0.526 & 1.033 \\
\hline 0.501 & 1.001 & 0.502 & 1.005 & 0.501 & 0.999 & 0.501 & 1.003 \\
\hline 0.334 & 1.002 & 0.334 & 1.004 & 0.333 & 0.999 & 0.334 & 1.002 \\
\hline 0.334 & 1.001 & 0.335 & 1.003 & 0.334 & 1.000 & 0.334 & 1.002 \\
\hline 1 & - & 0.534 & 1.168 & 0.462 & 0.873 & 0.514 & 1.075 \\
\hline 0.375 & 1.125 & 1 & - & 0.284 & 0.745 & 0.396 & 1.228 \\
\hline 0.247 & 0.909 & 0.217 & 0.767 & 1 & - & 0.244 & 0.893 \\
\hline 0.468 & 1.068 & 0.513 & 1.283 & 0.415 & 0.862 & 1 & - \\
\hline
\end{tabular}

\section{Copyrights}

Copyright for this article is retained by the author(s), with first publication rights granted to the journal.

This is an open-access article distributed under the terms and conditions of the Creative Commons Attribution license (http://creativecommons.org/licenses/by/4.0/). 